\title{
Cash Management Practice and Medium Scale Enterprises performance: Perspective of Selected Food and Beverages Firm in Oyo state Nigeria
}

\author{
Oladejo M.O, Akande O.O, YinusOluwaseun \\ Department of Management and Accounting, Faculty of Management Sciences \\ LadokeAkintola University of Technology, Ogbomoso, Oyo State, Nigeria.
}

\begin{abstract}
This study examined empirically the impact of cash management on the performance of SMEs food and Beveragemanufacturing firms in Oyo state. Primary data were employed in this study. Structured questionnaire was employed in the course of gathering relevant data for the study and administered purposively on Fifty (50) personnel of Ten (10 )SMEs food and Beveragemanufacturing firms in Oyo state selected through a random sampling technique. Out of the fifty questionnaire administered only forty were filled-in, returned and useful for the purpose of the study. Descriptive analysis was adopted in analyzing the data and the formulated Hypothesis were tested through the use of chi-square Analysis.Findings revealed that Firms possess or hold cash for transactional precaution and speculative purpose, meeting the day to day bills as they fall due, provision of fund for emergency obligation and ensuring opportunities in futuristic dealings form parts of responsibilities of general managers which require skillful management capabilities, Therefore, effective cash management significantly influence performance of Foods and Beverage Manufacturing SMEs. Also the result of tested hypothesis $\left(X^{2}\right.$ cal-19.8 $>X^{2}$ tab-0.352) revealed that Cash management had significant influence on the performance of Food and Beverages manufacturing SMEs. Base on the findings it was recommended that Surplus cash should be put in short term investment (e.g. fixed deposit) that are highly liquid and of low risk. This will enable maintenance of minimum cost as cash balance is optimally controlled. Medium Scale Food and Beverages Manufacturing Firm should embrace cash budget System for cash planning.
\end{abstract}

Keywords: Cash management; Cash control; Medium Scale Food and Beverages Manufacturing Firm; Business Performance

\section{INTRODUCTION}

Cash is ready money in the bank or in the business. The flow of cash in and out of a business over a period of time must be watched, controlled and managed. Cash is the vital component of the working capital because it keeps a business running. It is the hub around all financial matters centre. Thus, management of cash is crucial for the success of an enterprise. The adequacy of cash and other current assets, together with their efficient handling, virtually determines the survival or extinction of a business concern.. It is the basic input needed to keep the business running on a continuous basis.(Abu,2005). Cash is the basic input required to keep the business running on a continuous basis and it is also the ultimate output expected to be realized by selling the services or products manufactured by the firm (Pandey, 2010).

Cash management is imperative in every business organization as cash is said to be the life blood of any business (Chartered Institute of Management Accountant, CIMA, 2002). The essence of cash management is to ensure positive cash flow for smooth business operational performance. Precisely, cash and marketable securities are the two components of cash management which financial manager must maintain at low cost as possible. It forms an integral part of working capital management. Hence, it is considered as part of the scope of a good working capital management in modern businesses (Brealey and Myers, 2003). It is the process of ensuring that businesses have good cash balances to ensure that they continue to stay in business. The effective cash management can do much to ensure the success of a business while the inefficient management can lead not only to the loss of profit but also to the ultimate downfall of what otherwise might be a promising concern. In a nut shell, the aim of cash management should be to maintain adequate cash position to keep the company sufficiently liquid and to use the excess cash in some profitable ways. 
Furthermore, the process of managing corporate cash has become a major challenge for most Manufacturing SMEs, because of its significant impact on the results of a Operational performance of Micro and Small -scale Enterprises (Attom, 2012). The determination of problems in cash management involves identifying areas that are unique to solving cash problems in an organization. One of the problems faced by finance managers in managing cash is determination of appropriate source of fund for the company either to be used as the initial or working capital. Other challenges are identification of right investment opportunity for idle funds, non-cash planning, and determination of the optimal level of cash to be maintained by the company. More so, working capital management has been cited as a major problem for Manufacturing SMEs (Tauringana \& Afrifa, 2013), few studies have been carried out on cash management practices.

Evidence from literature showed that Effectivecash management can Improve Operational performance and ensure success of a business (Abioro, 2013; Bragg, 2004; Iggbinnosun, 2002). Howbeit, there is a dearth of literature regarding Cash Management impact on performance of food and beverages manufacturing in Nigeria. The question of whether cash management influence or worsens performance in a business organisation is still worthy of further research such as the one being undertaken in this study. In addition, despite the existence of these studies, very little attention has been given to Medium Scale Food and Beverages Manufacturing Firm. This means that the impact of cash management on the performance Medium Scale Food and Beverages Manufacturing Firmhas not received adequate research attention in Nigeria. This research therefore attempts to fill this gap by studying the situation and providing more empirical evidence on the impacts of cash management on the performance ofMedium Scale Food and Beverages Manufacturing Firmin Nigeria, specifically, the study will answer the following research question:

- Is there any significant relationship between cash management and Manufacturing Firm performance

- Does Manufacturing Firm prepare cash budget for effective cash management

- Does cash management influence firm performance.

\section{Research Hypothesis}

Ho:Cash management has no Significant Influence on the performance of Medium Scale Food and Beverages Manufacturing Firm.

\section{Literature Review ANd Conceptual Clarification}

Management is a generic term that is subjects to diverse interpretations. A number of different ideas are attributed to the meaning of management and to the work of a manager. Management is required in all areas of life. It enables operations of all types to be carried out effectively, smoothly and efficiently. It is the specific organ of modern institution. This is to say that performance and survival of any institutions depends on management. It is important to note that about ninety percent (90\%) of what makes business to succeed or failed comes from management. However, management is based on how organization are managed or specifically how manager(s) can help other members of the organization set and achieve a series of goals and objectives.

Cash management is a main area of working capital management. Other parts of it are inventory management, credit management and management of short-term liabilities. Cash management covers the management of the company's cash in the normal course of business i.e. making sure the company always has enough cash on hand to meet its bills and expenses, and investing any surplus cash (CIMA, 2002). Considering all descriptions and definitions above, it can be summarized that cash management entails all actions and activities necessary to maintain appropriate levels of cash to meet operational requirements of a company. Cash-flow control is therefore crucial to ensuring that a business remains liquid and able to meet payment obligations. This is carried out through the effective management of cash receipts and payments, cash balances and cash transfers between the different parts of a business (Bragg, 2004).

According to Pandey (1999) cash management involves managing the money or cash of the firm in order to attain both maximum cash availability and maximum profit. Cash management is concerned with the managing of: 
1. Cash flows into and out of the firm

2. Cash flows within the firm and

3. Cash balances held by the firm at a point of time by financing deficit or investing surplus cash.

Aborode, 2005 opined that cash management are reconciliatory efforts or activities of meeting cash disbursement needs and minimizing funds committed to cash balances which are conflicting and mutually contradictory.Moreover, cash management is pivotal part of working capital management functions where sound cash position is being maintained with a view to meeting the purpose of holding it and ensuring balanced liquidity position for the firm and optimum profitability. Positive net cash flow (that is when there is excess of inflow or of cash over outflow) should be maintained rather than negative net cash flow.

\section{Efficient Cash Management and Business Performance}

Studies reveal that Cash management is the key aspects of efficient working capital management which involves planning and controlling cash flows into and out of the business. It concerned with optimizing the amount of cash available, maximizing the interest earned by spare funds not required immediately and reducing losses caused by delays in the transmission of funds. Holding cash to meet short term- needs incurs an opportunity cost equal to the return which could have been earned if the cash had been invested or put to productive use. However, reducing this opportunity cost by operating with small cash balances will increase the risk of being unable to meet debts as they fall due, so an optimum cash balance should be found. (Wetson and Copeland, 2008).

Efficient cash management involves the determination of the optimal cash to hold by considering the trade-off between the opportunity cost of holding too much cash and the trading cost of holding too little (Ross et al., 2011) and as stressed by Atrill (2003), there is the need for careful planning and monitoring of cash flows over time so as to determine the optimal cash to hold. Abel (2008) argues that cash is crucial in every business in terms of enhancing its survival and prosperity. Marfo-Yiadom (2002) also noted that cash is the hub and most coveted of all the assets of any business. Good cash management can have a major impact on working capital management of a business and overall performance of business. Cash management is a broad term that refers to the collection, concentration, and disbursement of cash. It encompasses a business's level of liquidity, its management of cash balance, and its short-term investment strategies (Cardaralla: toni, 2010).

Strong cash management through proper cash planning will create growth of small scale businesses. Cash planning helps in forecasting cash inflows and out flows and thus management will store only adequate cash needed to meet obligations. (Azmat; Samaratunge, 2009). Proper cash management through investment of surplus cash, enhances growth of businesses as the firm will benefit profits from invested cash and cash at hand will help to meet current obligations (Brinchk; Hans; Gemuenden, 2011).efficient cash management means more than just preventing bankruptcy. It improves the profitability and reduces the risk to which the firm is exposed (Davidson: Charles, 2008). Cash management is particularly important for new and growing businesses, most especially manufacturing process and beverages firms.

\section{Motives for Holding Cash}

According to the notable economist, (Keynes, 1973) there are three main motives for holding cash and they are as follows:

\section{Transactionary Motive}

This is the major reason why corporate bodies hold cash. Cash is held in the ordinary course of business for day to day operation. This motive requires a firm to hold cash to conduct its business, the need to hold cash for this purpose rests on the fact that there is no perfect synchronization between cash receipts and payments.

\section{$>$ Precautionary Motive}

Cash is held to provide cushion or buffer to withstand unexpected emergency cash outflows. It is the need to hold cash to meet contingencies in the future. Cash held serves as safety margin against occasional unforeseen but compelling contingent payments in the future. Holding cash under this motive is to provide cushion to withstand unexpected emergency cash flows (Olowe, 1998). 


\section{$>$ Speculative Motive}

The speculative motive relates to holding of cash to seize an advantage of investment opportunities which may arise from time to time. Cash is required for taking advantage of unusually profitable opportunities which may suddenly occur. According to Van Horne (2002), firms must decide the quantum of cash to be held for motives identified above. Amount of cash to be held is influenced by the following factors;

- The expected cash flow.

- The degree of variation between the expected and actual net cash flow.

- The maturity structures of the firms liabilities.

- The firm's ability to borrow at a short notice in event of any emergency.

- The philosophy of management regarding liquidity and risk of insolvency.

- The efficient planning and control of cash.

Igbinosun (2002) asserted that since business firms do not engage in speculations, motives to hold cash and marketable securities are mainly Transactionary and precautionary motive. He stated the following as factors determining the business firms level of cash requirements; efficient planning and control of cash, business firm's expected cash flow, borrowing capacity, firm's management attitude to risk, debt repayment schedule, size of the organization and cost of capital.

Literature reveal that there are additional reason for holding cash which he termed as compensating motive. That is, banks are compensated for providing certain services and loans. Such as clearance of cheque, supply of credit information, transfer of fund and so on. While for some of these services banks charge a commission or fee, for others they seek indirect compensation. The minimum cash balance maintained at the bank by the firm cannot be utilized by the firms for either transaction or precautionary purposes, the banks themselves can use the amount to earn a return. Such balances are compensating balances. This also includes minimum balance maintained in the bank account as a condition precedent to the grant of loan. (Akinborode, 2005)

\section{Importance of Cash Management}

Studies reveal that Cash management is concerned with managing cash flows (within the firm, in and out of the firm) and cash balances (by financing deficit or investing surplus cash). The surplus cash has to be invested while deficit has to be borrowed. This shows that cash management task is vehemently important for any financial manager. Firstly, cash management seeks to accomplish cash cycle at a minimum cost. Secondly, it seeks to maintain adequate control over cash position to keep the firm sufficiently liquid and to use excess cash in some profitable way. This is as a result of its unproductive nature unlike fixed assets or inventories; it does not produce goods for sales. Therefore, cash management assumes more importance than other current assets because cash is the most significant and the least productive asset that a firm holds. Thirdly, the management of cash if also important because it is difficult to predict cash flows accurately, particularly the inflows, and there is no perfect coincidence between the inflows and outflows of cash. Cash management as the basic tool of running a business and cash forecast as the working tool of cash management. (Chandra, 2008; Tuller, 2008; Pandy, 2010; Mauchi, 2011).

Furthermore, cash management has helped to develop some techniques to manage cash affairs in such a way as to keep cash balance at a minimum level, anticipate the future cash flows, need of the firm, reduce the possibility of idle cash balances and cash deficits. (Pandy, 2005).

\section{Forces of cash management}

Studies show that there is need for proper management of cash, since it is the most important current asset for the operation of business. The firm should keep sufficient cash, neither more or less. Cash shortage will disrupt the firms operations, while excessive cash will simply remain idle, without contributing anything towards the firm's profitability. (Pandy, 2010) suggested the following as facets of cash management;

$>$ Cash planning

$>$ Managing cash flows

$>$ Determining the target cash balance 


\section{Cash Planning and Budgeting}

Cash planning is a technique to plan for and control the use of cash. It protects the financial conditions of the firm by developing a projected cash statement from a forecast of expected cash inflows and outflows for a given period. Thus, cash planning helps to anticipate future cash flows and needs of the firm thereby reducing the possibility of idle cash (which lowers firms profitability) and cash deficit (which can cause firm's failure). Cash planning is not a science but rather an on-going, iterative process that involves many parts of the organization. It can be done on daily, weekly, or monthly basis. The period and frequency of cash planning depends on the size of the firm and the philosophy of management. Bragg (2004) stated that "A cash forecast, or cash plan, or cash budget, is a projection of the anticipated cash receipts and disbursements and the resulting cash balance within a specified period". While Tuller (2008) describes cash management as the basic tool of running a business and cash forecast as the working tool of cash management.

\section{Managing Cash flows}

Once cash budget has been approved, and appropriate net cash flow established, the financial manager should ensure that there does not exist a significant deviation between projected cash flows and actual cash flows. To achieve this, there will have to be proper control of cash collections and disbursements. According to Pandey (2010) Cash management in the modern corporation involves two simple rules: \ Speed up cash collection (Cash Inflow) - minimize collection float, I Slow down cash disbursement (Cash Outflow) - maximize disbursement float. Ross, Westerfield, Jaffe\& Jordanand (1991) stated that the objective of cash management in cash collection is to speed up collections and to reduce the lag time between the time consumer pays their bills and the time the cheques are collected. While the objective of cash management in disbursements is to control payments and minimize the cost associated with making payments. The rule is to accelerate collections and delay disbursement. Therefore it can be concluded that objective of management of collection and disbursement is to collect it faster, keep it longer and spend it slower.

\section{Determining the target cash balance}

According to Pandey (2010) one of the primary responsibilities of a financial manager is to maintain a sound liquidity of the firm so that dues may be settled in time. Gallagher (2000) opined that cash management involves a tradeoff between the need for liquidity and desire for profitability. The more cash a firm holds, the more liquid it becomes, however piling up funds to sustain liquidity will prevent fund from being invested in long term, high return producing assets. The trade -off between benefits and cost of liquidity is one essential part of cash management If the firm maintains a small balance, its liquidity position becomes weak and it will suffers paucity of cash to make payments. It may have to sell marketable securities, if available, or borrow and this involves transaction cost. On the other hand, if the firms maintains a higher level of cash balance, it will have a sound liquidity position, but forego the opportunity to earn interest the potential interest lost on holding large cash balance involves an opportunity cost to the firm. Thus, the firm should maintain an optimum cash balance, neither a small nor a large cash balance. The cash balance will be at its optimum position when the transaction cost and risk of a small cash balance is matched or equals the opportunity cost of too large a balance.

\section{Methodology}

The population of the study comprises 257 Food and beverages Processing SMEs in Oyo state. (http://www.businesslist.com.ng/category/food-processing). Ten(10) Medium Scale Food and Beverages Manufacturing Firm was selected randomly. Purposive sampling technique was used to select 50 personnel across all the selectedMedium Scale Food and Beverages Manufacturing Firm in Accounting and Finance Department. Fifty (50) Questionnaires were administered and distributed to the personnel across all the Selected Medium Scale Food and Beverages Manufacturing Firm. This was done in such a way that all the Ten (10) Medium Scale Food and Beverages Manufacturing Firm were represented with each firm having five (5) respondents. Out of the fifty questionnaire admistered only forty were filled-in, returned and useful for the purpose of the study. Descriptive analysis was adopted in analyzing the data and the formulated Hypothesis were tested through the use of chi-square Analysis. On validity, the decision on whether to accept or reject would be based on comparison between the chi-square Calculated and chi-square tabulated. 


\section{RESUlT AND DiSSCUSSION}

\section{Respondents' Charactertistics and Classfication}

From the Table 1, considerable proportion of questionnaire were retrieved, while 10 (20\%) were not retrieved. This shows that the result of the analysis and outcome generalization will be reliable.In table 2: It is shown that majority of the respondents are female i.e. $25(612.5 \%)$ while fifteen $(37.5 \%)$ are males.As shown in table 3 majority of the respondents that is twenty-six (26) respondents fall within the age group of $31-50$, which constitute $65 \%$ of the total respondents. Meanwhile, $25 \%$ of the respondents fall within $18-30$ years, $7.5 \%$ of the respondents fall within $51-60$ years only, one $(2.5 \%)$ respondent is within 60 years and above.

Table 4 below illustrates the breakdown of educational qualifications of the respondents. Fifteen $(37.5 \%)$ and fourteen (35\%) respondents are having ' $\mathrm{O}$ ' level and OND/NCE qualifications. While thirty-two percent $(32.5 \%)$ of the respondents are having HND/BSC and post graduate qualifications and they are ten and three in number. Table5 shows that thirteen $(32.5 \%)$ respondents form the officers at level of management while fourteen (35\%) respondents are middle level management officers, The organization has a total number of fifteen $(37.5 \%)$ respondents from junior level cadre.

From the table 6 below, it is shown that no worker works less than 5 years in the organization, while majority of the officers, that is, twenty-six (65\%) respondents have been in the company's system between ten and twenty years. Fourteen number (35\%) respondents are in the company for over and above twenty years.

Table1. Questionnaire distribution Analysis

\begin{tabular}{|c|c|c|}
\hline Questionnaire & Frequency & Percentage $\%$ \\
\hline Retrieved & 40 & 80 \\
\hline Un-retrieved & 10 & 20 \\
\hline Total & $\mathbf{5 0}$ & $\mathbf{1 0 0}$ \\
\hline
\end{tabular}

Source: Field Survey, 2016.

Table2. Respondents' Sex Distribution

\begin{tabular}{|c|c|c|}
\hline Respondents & Frequency & Percentage \% \\
\hline Male & 15 & 70 \\
\hline Female & 25 & 30 \\
\hline Total & $\mathbf{4 0}$ & $\mathbf{1 0 0}$ \\
\hline
\end{tabular}

Source: Field Survey, 2016.

Table3. Respondents' Age Group Distribution

\begin{tabular}{|c|c|c|}
\hline Age Group of Respondents & Frequency & Percentage \% \\
\hline $18-30$ & 10 & 25 \\
\hline $31-50$ & 26 & 65 \\
\hline $51-60$ & 3 & 7.5 \\
\hline 60 and above & 1 & 5 \\
\hline Total & $\mathbf{4 0}$ & $\mathbf{1 0 0}$ \\
\hline
\end{tabular}

Source: Field Survey, 2016.

Table4. Respondents' Educational Qualification Distribution

\begin{tabular}{|c|c|c|}
\hline Qualification & Frequency & Percentage \% \\
\hline 'O' Level & 15 & 37.5 \\
\hline NCE/OND & 14 & 20 \\
\hline HND/BSC & 10 & 35 \\
\hline Post Graduate & 3 & 20 \\
\hline Total & $\mathbf{4 0}$ & $\mathbf{1 0 0}$ \\
\hline
\end{tabular}

Source: Field Survey, 2016.

Table5. Respondents' Distribution by Management Mix

\begin{tabular}{|c|c|c|}
\hline Management Level & Frequency & Percentage \% \\
\hline Senior level & 13 & 32.5 \\
\hline
\end{tabular}


Cash Management Practice and Medium Scale Enterprises performance: Perspective of selected Food and Beverages Firm in Oyo state Nigeria

\begin{tabular}{|c|c|c|}
\hline Middle level & 14 & 35 \\
\hline Junior level & 15 & 37.5 \\
\hline Total & $\mathbf{4 0}$ & $\mathbf{1 0 0}$ \\
\hline
\end{tabular}

Source: Field Survey, 2016.

Table6. Respondents' Distribution by Work Experience

\begin{tabular}{|c|c|c|}
\hline Years of Experience & Frequency & Percentage \% \\
\hline Below 5 years & 0 & NIL \\
\hline 10-20 years & 26 & 65 \\
\hline 21 years and above & 14 & 35 \\
\hline Total & $\mathbf{4 0}$ & $\mathbf{1 0 0}$ \\
\hline
\end{tabular}

Source: Field Survey, 2016.

\section{Perception of Respondent on Cash Management Practice and Business performance}

The table7 below indicates that thirty-six (90\%) respondents believe that the manufacturingFirm's prepares cash budget, while four $(10 \%)$ respondents are of the opinion that the company does not prepare any cash budget. Therefore, with the opinion of the majority of the respondents, researcher can say that the manufacturing Firm's does prepare cash budget.

According to table 8, it show that thirty-two (80\%) respondents believe that the firms has experienced the period of liquidity problem while eight $(20 \%)$ respondents do not believe that there is period of liquidity problem. As a result, by virtue of the majority over average of eighty percent, one can say that the manufacturingFirm's has experienced liquidity problem. According to the table 9 below, all respondents (100\%) are of the same opinion that the Firm's occasionally has cash surplus. This shows that the company actually needs the knowledge of cash management by virtue of its cash surplus. Analysis from table10 below, it shows that majority of respondents, that is, thirty-eight (95\%) respondents believe that the cash surplus of the company is usually kept safe in the current account. This depicts the idleness of cash in the current account according to the respondents' response.

As shown in table 11 below, (72.5\%) respondents believe that there is relationship between Manufacturing firm and cash inflow, (12.5\%) disagree. Therefore, it can be conclude there is relationship between Manufacturing firm and cash inflowbecause is the way at which the firm's inadequate cash problem is solved.

Analysis from table 12 below signify that thirty (75\%) respondents are of the opinion that overdraft saves the manufacturing Firm's in an emergency situation while ten $(25 \%)$ respondents do not believe that company does not adopt overdraft in an emergency cash requirement. Therefore, according to the respondents' responses, the company adopts overdraft when there is emergency cash requirement.From the table 13 below, it is observed that majority of the respondents that is $(72.5 \%)$ believe that manufacturingfirm need to manage cash effectively, $(12.5 \%)$ disagree while $(5 \%)$ were uncertain. Therefore, it can be concludethere is relationship between Manufacturing firm and cash inflowbecause is the way at which the firm's inadequate cash problem is solved. Therefore, it can be conclude that the manufacturing Firm's does not put the company's excess into any short-term investment

Table7. Response on (Q1): Does your firm prepared cash budget?

\begin{tabular}{|c|c|c|}
\hline Response & Frequency & Percentage \% \\
\hline Yes & 36 & 90 \\
\hline No & 4 & 10 \\
\hline Total & $\mathbf{4 0}$ & $\mathbf{1 0 0}$ \\
\hline
\end{tabular}

Source: Field Survey, 2016.

Table8. Response on (Q2): Has your firm Experience liquidity problem?

\begin{tabular}{|c|c|c|}
\hline Response & Frequency & Percentage \% \\
\hline Yes & 32 & 80 \\
\hline No & 8 & 20 \\
\hline Total & $\mathbf{4 0}$ & $\mathbf{1 0 0}$ \\
\hline
\end{tabular}

Source: Field Survey, 2016. 
Oladejo M.O et al.

Table9. Response on (Q3): Does yourfirm occasionally have cash surplus?

\begin{tabular}{|c|c|c|}
\hline Response & Frequency & Percentage \% \\
\hline Yes & 40 & 100 \\
\hline No & - & - \\
\hline Total & $\mathbf{4 0}$ & $\mathbf{1 0 0}$ \\
\hline
\end{tabular}

Source: Field Survey, 2016.

Table10. Response on (Q4): Does yourfirm keep cash surplus in the current account?

\begin{tabular}{|c|c|c|}
\hline Response & Frequency & Percentage \% \\
\hline Yes & 38 & 95 \\
\hline No & 2 & 5 \\
\hline Total & $\mathbf{4 0}$ & $\mathbf{1 0 0}$ \\
\hline
\end{tabular}

Source: Field Survey, 2016.

Table11. Response on Q5: There is relationship between Manufacturingfirm and cash inflow?

\begin{tabular}{|c|c|c|}
\hline Response & Frequency & Percentage \% \\
\hline Strongly Agreed & 13 & 32.5 \\
\hline Agree & 20 & 50 \\
\hline Uncertain & 2 & 5 \\
\hline Disagree & 5 & 12.5 \\
\hline
\end{tabular}

Source: Field Survey, 2016.

Table12. Response on Q6:Does manufacturing firmmake use of overdraft when there is emergency cash requirement?

\begin{tabular}{|c|c|c|}
\hline Response & Frequency & Percentage $\%$ \\
\hline Yes & 30 & 75 \\
\hline No & 10 & 25 \\
\hline Total & $\mathbf{4 0}$ & $\mathbf{1 0 0}$ \\
\hline
\end{tabular}

Source: Field Survey, 2016.

Table13. Response on Q7: Manufacturing firm need to manage cash effectively

\begin{tabular}{|c|c|c|}
\hline Response & Frequency & Percentage \% \\
\hline Strongly Agreed & 13 & 32.5 \\
\hline Agree & 20 & 50 \\
\hline Uncertain & 2 & 5 \\
Disagree & 5 & 12.5 \\
\hline
\end{tabular}

Source: Field Survey, 2016.

Test of Hypothesis

\section{Restatement of Hypothesis}

Ho: Cash management has no Significant Influence on the performance of Medium Scale Food and Beverages Manufacturing Firm.

Decision Rule: If $\mathrm{X}^{2} \mathrm{cal}>\mathrm{X}^{2}$ tal, the null hypothesis is rejected and the alternative hypothesis is accepted with the necessary conclusion made.

As shown in table 15 and 16 below a total average number of (32.5\%) respondents strongly agree with the hypothesis, the total average number of respondents that agree with the hypothesis are 20 respondents $(50 \%),(12.5 \%)$ respondents disagree with the stated hypothesis while $5 \%$ of the respondents are yet to decide. The result of Analyse show that $X^{2}$ cal is 19.8 and $X^{2}$ tab $=0.352$ at $95 \%$ Level of significance. This signify that chi- square calculated is greater than chi- square tabulated $\left(\mathrm{X}^{2} \mathrm{cal}>\mathrm{X}^{2} \mathrm{tab}\right)$.

Since the chi- square $X^{2}$ cal $>X^{2}$ tab, Hence the null hypothesis was rejected while the alternative hypothesis was accepted. Which show that Cash management has significant influence on the performance of Medium Scale Food and Beverages Manufacturing Firm.Therefore, there is a relationship between cash management and performance of business organization. 
Cash Management Practice and Medium Scale Enterprises performance: Perspective of selected Food and Beverages Firm in Oyo state Nigeria

Table15. Analyses of Respondent on Cash management and Medium Scale Food and Beverages Manufacturing Firm Performance

\begin{tabular}{|c|c|c|c|c|c|c|c|c|c|}
\hline Question & Responses & \multicolumn{2}{|c|}{ Strongly Agree } & \multicolumn{2}{c|}{ Agreed } & \multicolumn{2}{c|}{ Uncertain } & \multicolumn{2}{c|}{ Disagree } \\
\hline & & Freq. & $\mathbf{\%}$ & Freq. & $\mathbf{\%}$ & Freq. & $\mathbf{\%}$ & Freq. & \% \\
\hline Q5 & 40 & 13 & 32.5 & 20 & 50 & 2 & 5 & 5 & 12.5 \\
\hline Q7 & 40 & 13 & 32.5 & 20 & 50 & 2 & 5 & 5 & 12.5 \\
\hline Average & $\mathbf{4 0}$ & $\mathbf{1 3}$ & $\mathbf{3 2 . 5}$ & $\mathbf{2 0}$ & $\mathbf{5 0}$ & $\mathbf{2}$ & $\mathbf{5}$ & $\mathbf{5}$ & $\mathbf{1 2 . 5}$ \\
\hline
\end{tabular}

Table16. Testing of Hypothesis using Chi-Square $\left(X^{2}\right)$

\begin{tabular}{|c|c|c|c|c|}
\hline Qi & Ei & (Qi-ei) & (Qi-ei)2 & $\frac{(\text { Qi-ei) }}{\mathbf{e}}$ \\
\hline 13 & 10 & 3 & 9 & 0.9 \\
\hline 20 & 10 & 10 & 100 & 10 \\
\hline 2 & 10 & -8 & 64 & 6.4 \\
\hline 5 & 10 & -5 & 25 & 2.5 \\
\hline 40 & $\mathbf{4 0}$ & & & $\mathbf{X}^{\mathbf{2}}$ cal=19.8 \\
\hline
\end{tabular}

\section{CONCLUSION AND RECOMMENDATION}

Findings show that that there is significant relationship between Cash Management and performance of Medium Scale Food and Beverages Manufacturing Firm. More also, cash management plays quantitative and qualitative role in making short term and long term investment decision.Furthermore, the researcher concluded that effective reconciliatory cash management techniques resolves liquidity crisis as a result of sourcing for cash and using of cash in the course of the activities of business organization. Balanced cash position should be maintained. The Result of tested Hypothesis reveals thatCash management had Significant influence on the performance of Medium Scale Food and Beverages Manufacturing Firm. Base on the findings the following recommendations were made:

$>$ Surplus cash should be put in short term investment (e.g. fixed deposit) that are highly liquid and of low risk. This will enable maintenance of minimum cost as cash balance is optimally controlled.

$>$ Food and Beverages Manufacturing SMES should embrace cash budget System for cash planning most importantly by adopting an effective period.

\section{REFERENCES}

Abel, M. (2008). The Impact of Working Capital Management on Cash Holdings: An Quantitative Study of Swedish Manufacturing SMEs. Mid Sweden University, Faculty of Human Sciences, Department of Social Sciences.

Abioro, 2013; The impact of cash management on the performance of manufacturing companies in Nigeria, Uncertain Supply Chain Management 1 (2013) 177-192. www.GrowingScience.com/ uscm.

Aborode, R. (2005). Strategic Financial Management. Lagos: Eltoda Ventures Ltd. pp. 415 - 433.

Abu Tabanja. a.(2005).Cash Management of the Selected Jordanian Large Scale Public Limited Industrial Companies, Dirasat, Administrative Sciences, Volume 32, No. 1.

Atrill, P. (2003). Financial Management for Non- Specialists (3rd ed.)

Attom, B.E. \& Mbroh, J.K (2012). Financial Management Made Easy, Accra: Adwinsa Publications (GH) Ltd. Brealey, A. R., Myers, C. S \& Allen, F. (2008). Principles of Corporate Finance, New York: McGraw-Hill/Irwin.

Bragg, S. M. (2004). Controller's guide to planning and controlling operation. New Jersey: John Wiley \& Sons, Inc.

Brealey, A. R. \& Myers, C. S. (2003). Principles of Corporate Finance, New York: McGraw-Hill Companies Inc.

Brinchk Mann, Jan;Salomo, Soeren; Gemuenden, Hans Geog. Entrepreneurship theory and practice, march 2011 vol.35 issue 2, p217-234, 27p.

Cardarella, Toni. "Small Businesses Must Put Effort into Getting Customers to Pay on Time." KnightRidder/Tribune Business News, September 21, 2010. 
Chandra Prasanna (2008), Financial Management: Theory and Practice, 7th Ed, Tata McGraw-Hill Publishing Company Limited.

CIMA (2002).Preparing cash budget.Retrieved January 20, 2012, from http:// www.cimaglobal.com/ Documents/Imported Documents/article_web_nov02.pdf.

Davidson, Jeffrey P., and Charles W. Dean. Cash Traps: Small Business Secrets for Reducing 35 Costs and Improving Cash Flow. New York: Wiley, 2008.

Fasoranti, M, Akinrinade, O. \&Ajibefun I. (2006). Impact of Micro credit and training on efficiency of small scale enterprises: Evidence from National Directorate of Employment loan/training programmes in Nigeria. The social sciences, vol.1 No.4 Pp.264-269.

Gallagher, T. (2000).Financial Management Principle \& Practice (2nd Ed.) New Jersey: Prentice Hall Inc.

Gitman, L. J. (2009). Principles of Managerial finance (12th ed.). Bostos, MA: Pearson Prentice Hall.

Igbinosun, F. E. (2002). In search of excellent cash management and control strategies in business endeavours.The Nigerian Accountant Journal of the Institute of Chartered Accountants of Nigeria. 35(4) 20-33.

Keynes, J. M. (1973). The general theory of employment interest and money. (14th ed.). LondonAzmat, Fara, Samaratunge, Ramanie. Jounal of business ethics, Dec 2009, vol.90, issue 3, p 437- 452, p16. Banker, Rajiud; Huang, Rong; Natrajan, Ramachandran. Journal of account reasaerch, June 2009, vol.47 issue 3, p647-678, 32p

Mauchi F. (2011).The effectiveness of cash management policies: a case study of Hunyani flexible products. International Research Journal, 2(7), 1299-1305.

Pandey I M (2010), Financial Management, 10th Ed, Vikas Publishing House Pvt Ltd

Pandey I. M. (1999) Financial Management ( $8^{\text {th }}$ Edition) New Delhi: Vikas Publishing House PVT Ltd.

Ross, S. A., Westerfield, R. W., \& Jordan, B. D. (1991). Fundamentals of corporate finance. New York: Irwin Inc.

Ross, S. A., Westerfield, W. R., Jaffe, F.J., \& Jordan, D. B. (2011) Core principles and applications of corporate finance: Global edition. (3rd ed.), New York, McGraw Hill/ Irwin.

Tauringana, V. \&Afrifa, A. G. (2013).“The relative importance of working capital management and its components to SMEs' profitability", Journal of Small Business and Enterprise Devleopment, Vol. 20, (3), pp. 453-469.

Tuller, L. W. (2008). Finance for non-financial managers and small business owners (2nded.). Canada, Adams Business.

Weston, I. F. \& Copeland, T. E. (2008). Managerial Finance (12th ed.): The Dryden Press. 